\title{
The Role of Self-Esteem as a Predictor on Dispositional Gratitude of the Victim of Psychological Neglect in Childhood
}

\author{
Micheel Kalalo ${ }^{1}$ Naomi Soetikno ${ }^{1} J^{2} s s i c a ~ C h a n d h i k a{ }^{1 *}$ \\ ${ }^{1}$ Psychology Undergradautate Program, Faculty of Pscyhology, Universitas Tarumanagara, Jakarta 11440, Indonesia \\ *Corresponding author. Email: jessica@fpsi.untar.ac.id
}

\begin{abstract}
One of the individual needs during childhood development is emotional needs, whereas this can be satisfied when parents carry out their responsibilities in providing guidance and warmth. Psychological neglect behaviour in children occurs when parents do not present supervision and fondness. In previous studies, it was dominantly found that individual victims of psychological neglect have negative self-esteem and have minimal gratitude values that could harm lives. This study aims to look at the role of gratitude toward to selfesteem in early adult individuals who are victims of psychological neglect in childhood. The data were collected using the Rosenberg self-esteem scale and the gratitude questionnaire six form. The study was carried on 170 subjects of psychological neglect in childhood victims, aged 21-40 years old using a nonexperimental quantitative research design. This study found that there is a significant role of self-esteem as predictor on gratitude, so that self-esteem specifically affect gratitude in the amount of 39,3\%.
\end{abstract}

\section{Keywords: Psychological Neglect, Self-Esteem, Dispositional Gratitude}

\section{INTRODUCTION}

Psychological neglect is a form of negative experiences that occur in children under 18 years which can hurt the mental health and emotional development of the victim $[1$, 2, 3]. One form referred to by Brandt [4] is secondguessing the form of emotions the child expresses and gives the impression that their feelings are meaningless. During the development period, children need support from their parents in shaping themselves physically and psychologically others are such as life goals, satisfaction, life, self-concept development, academics, and life values $[5,6,7,8,9,10]$. When support is not fulfilled and there is neglect, Greger et al., [11] the psychological aspects of children can be disturbed when viewed through selfesteem, especially in individuals in adulthood [12]. Also, $\mathrm{Wu}$ et al. and Crandall et al., [13, 14] found a lack of dispositional gratitude in individuals the victims of psychological neglect.

However, the previous study still found discrepancies in the results which can be caused by the differentiation in the characteristics, location, and size of the sample. Therefore, the researcher wants to look the role of gratitude as a predictor of the self-esteem of individuals who are victims of childhood psychological neglect in adulthood.

\subsection{Related Work}

According to the generation type of assumptions, we divided the existed work into three categories.

\subsubsection{Dispositional Gratitude}

McCullough et al., [15] explained that dispositional gratitude is how the attitude of an individual responds to the good behavior of others that has a positive impact and experience. This behavior is based on several factors, namely welfare, simplicity, prosocial behavior, and religious values $[15,16]$.

Even though grateful behavior is unidimensional, it can be seen from the aspects of (a) intensity, (b) frequency, (c) range, and (d) density. [15, 16]. This can affect many many aspects of life, one of which is being part of the process of acceptance and recovery from negative feelings such as bitterness and hatred [17].

\subsubsection{Self-Esteem}

Papalia et al., [18] explained that self-esteem is a part of development since early childhood, this is necessary for individuals to evaluate themselves to achieve selfactualization [19]. Rosenberg et al., [20] stated that selfesteem is an individual's attitude towards themselves to fully assess how they behave positively or negatively. 
The component that divides self-esteem in self-assessment is divided into two parts, namely self-confidence as the main function in reviewing self-action, and selfdeprecation as a negative connotation component that criticizes individuals [21].

The factor mentioned by Erikson in determining selfesteem is how individuals behave in handling productive work [18]. Apart from that, Rosenberg et al.,[20] stated that socio-economic, religion, and ethnicity were also affected even though religion and ethnicity were still influenced by other things such as parental interests and social class.

Self-esteem is important to promote success in childhood [18], influencing anxiety [22, 23], and defensive behavior [24 Vaughan Johnston]. Also, negatively when the individual's self-esteem is low in the adolescent stage, it can predict depressive symptoms in the early adulthood stage [25].

\subsubsection{Psychological Neglect}

Bernstein et al., [26] and Teicher et al., [27] stated that psychological neglect is a condition where the basic needs of children such as emotional and psychological are not fulfilled. According to Baumrind [28], neglect can occur when the behavior of parents towards children has a low level of support and demandingness.

The forms of psychological neglect behavior referred to are parenting behavior that is not aligned, does not meet emotional needs, does not understand weaknesses and thoughts, lack of attention, nurture, positive input, and support when experiencing any feelings, refusal to provide mental health care, restraint, unrealistic expectations, and ignorant behavior that lead to endangering children [26, 27, 29 Fanetti, 30 Tower].

These negative experiences can affect individuals in various aspects such as physicality in children such as failure to thrive syndrome $[18,30]$, affective levels such as anxiety, depression, immaturity, suicidal thoughts, and low self-esteem [31].

\subsection{Our Contribution}

Theoretically, the results of these findings can provide theoretical and practical contributions in the world of positive psychology, clinical and social as well as institutions or agencies that are involved in the social field, especially child protection services. Practically, to be more aware of the issue of psychological neglect as well the impact on the condition of individual self-esteem and gratitude. useful for future parents to pay attention to attitudes of involvement and support in the growth of the child

\subsection{Paper Structure}

The rest of the paper is organized as follows. Section 2 introduces the background and measurements that this study use Section 3 methods and findings and discussion in Section 4. Section 5 we concludes the paper and presents direction for future research.

\section{BACKGROUND}

\subsection{Psychological Neglect, Self-Esteem, and Gratitude}

Previous study stated that when psychological needs arent fulfiled during childhood psychological development is hampered and can affect the level of psychological disorders, one of the inhibited psychological developments or growth is the one of person's self-esteem $[9,11]$.

Study showed that person's self-esteem have a significant correlation with gratitude [37, 40]. Others study support that when an individual have a high sense of self-esteem and gratitude they tend to have high altruistic attitude, and others who have low sense of self-esteem and gratitude have high suicide ideation and tendency $[33,38,39,41]$

\section{METHODS}

\subsection{Participants}

This research conducted by giving electronic questionnaire form to random young adult aged 21 to 40 years, not limited by gender, religion, ethnicity or socioeconomic status. Participant initially asked if they've expirienced psychological neglect in childhood by presenting these types of parents' behavior, namely: (1) not meeting emotional needs and feelings of affection by not providing care, attention, support to you when experiencing emotional distress or when feeling any emotional feelings (2) low supportive attitudes, understanding weaknesses, understanding thoughts, and/or give-provide supportive input, (3) behave in restraint, (4) ignore, ignore maladaptive behavior in children and ignore behavior that can put yourself in danger. (5) Refusal to provide access to mental health care and neglect their obligations to pay attention to children's growth. (6) inconsistencies in parenting that make individuals feel neither belong nor part of the family $[25,26,27,28,29,30]$ before continuing to the main part of the questionnaire measurements.

\subsection{Measurements}

According to the variables type we use two type of measurements.

\subsubsection{Gratitude Questionnaire Six Form}

The gratitude questionnaire-six item form (GQ-6) by McCullough et al., [15] is a unidimensional measurement tool used to measure positive gratitude. GQ-6 has 6 questions with 7 point likert scale. The validity of the 
measuring instrument using the Kolmogorov-Smirnov having alpha's Cronbach results $=0.743$ (Table 1). The results of the reliability test showed that no items were corrected - the total correlation score was below 0.2 , so no items were deleted.

Table 1 Alpha Cronbach GQ-6

\begin{tabular}{lll}
\hline GQ-6 & Number of items & $\begin{array}{l}\text { Alpha's Crobach } \\
\text { coefficients }\end{array}$ \\
\hline Gratitude & 6 & 0,743 \\
\hline
\end{tabular}

\subsubsection{Rosenberg Self-Esteem Scale}

Rosenberg self-esteem scale (RSES) [32] is a unidimensional measuring tool that has 10 questions that have been adapted into Indonesian so that it has 20 questions with a 5 point Likert scale. RSES is used to measure the overall level of individual self-esteem, the validity of the measuring instrument using the Kolmogorov-Smirnov obtained alpha's Cronbach value $=$ 0.950 (Table 2). The results of the reliability test showed that no items were corrected - the total correlation score was below 0.2 , so no items were deleted.

Table 2 Alpha Cronbach RSES

\begin{tabular}{lll}
\hline RSES & Number of items & $\begin{array}{l}\text { Alpha's Crobach } \\
\text { coefficients }\end{array}$ \\
\hline Self-esteem & 20 & 0,950 \\
\hline
\end{tabular}

\section{FINDINGS AND DISCUSSIONS}

Data were enterd into SPSS for analysis, descriptive statistics were used in the current study to found that 170 participants who endorsed a history of psychological neglect, $78,8 \%$ are females and $22,2 \%$ are males, majority are aged $21(35,9 \%)$, are students $(50 \%)$, lived in Jakarta $(31,2 \%)$, majority are high school graduates $(47,1 \%)$, mostly lived with immediate family $(69,4 \%)$, majority have 3 to 4 close friends $(35,3 \%)$, and $71,8 \%$ did not have non-academic achievements.

The description of the participant gratitude (Tabel 3) in this study is $\mathrm{M}=5.261$, means that participant has a high gratitude in their self. The description of the participant self esteem (Tabel 4) is $M=3.092$, means that participant has a high self-esteem.

Table 3 Descriptive mean of variable $Y$

\begin{tabular}{lll}
\hline GQ-6 & Hypotetical Mean & Empirical Mean \\
\hline Gratitude & 4.00 & 5.261 \\
\hline
\end{tabular}

Table 4 Descriptive mean of variable $X$

\begin{tabular}{lll}
\hline RSES & Hypotetical Mean & Empirical Mean \\
\hline Self-esteem & 3.00 & 3.092 \\
\hline
\end{tabular}

Using the linear regression analysis for testing the hypothesis of this research, found that gratitude affected self-esteem $(\mathrm{t}=10.425, p=0.000)$, wirh $\mathrm{R}^{2}=0.393$. these result means that the self-esteem has a role as a predictor of the gratitude in amount of $39.3 \%$ (Table 5).

Table 5 Linear Regression

\begin{tabular}{|c|c|c|c|c|c|}
\hline $\mathrm{R}$ & .627 & & & & \\
\hline R Square & .393 & & & & \\
\hline $\begin{array}{l}\text { Adjusted } \\
\mathrm{R}^{2}\end{array}$ & .389 & & & & \\
\hline Std. Error & .74097 & & & & \\
\hline & $\begin{array}{l}\text { Sum of } \\
\text { square }\end{array}$ & $\mathrm{df}$ & $\begin{array}{l}\text { Mean } \\
\text { square }\end{array}$ & $\mathrm{F}$ & Sig. \\
\hline Regression & 59.696 & 1 & 56.696 & 108.726 & $0.000^{\mathrm{b}}$ \\
\hline Residual & 92.239 & 168 & .549 & & \\
\hline Total & 151.935 & 169 & & & \\
\hline
\end{tabular}

Note: a. Dependent Variable: Gratitude; b. Predictors: (constant), Self-esteem

More test were run to compare the current variable to demographic descriptive data to find the describe the sample.

(1) When Kruskall wallis test was conducted to examine the difference on gratitude accordint to close friends quantity, a significant difference were found $(\mathrm{H}(2)=$ $30.130, p=0.000)$ among the three categories of participants ( 1 to 2 close friends $(M=65.88), 3$ to 4 close friends $(\mathrm{M}=75.21)$, and more than 4 close friends $(\mathrm{M}=113.74)$ ).

(2) One-way ANOVA was run to differenciate the selfesteem to the close friends quantity, we found that there is a significant difference between groups with $p=0.000$, further analysIs with Tukey HSD shows that there is significant difference between participants with 1 to 2 close friends and participants with more than 4 friends $(p=0.000)$, and between participants with 3 to 4 close friends and participants with more than 4 friends $(p=0.033)$.

(3) When Independent sample t-test was run to found the differenciation to other demographic data on selfesteem and non-academic achievement, we found there's a difference between groups with nonacademic achievement $(\mathrm{M}=3.329, \mathrm{SD}=0.777)$, and groups without non-academic achievements $(\mathrm{M}=$ 2.999, $\mathrm{SD}=0.814)$. With $\mathrm{t}(168)=2.407, \quad p=0.017$, and mean difference $=0.329$.

In contrast to the findings of Asif et al., [33] which stated that there was no significant relationship between gratitude and self-esteem, this study found a significant difference. This can be caused by differences in participant characteristics, sample size, and sample location. Also, it was found that other things that affect the value of gratitude besides religiosity, welfare, and prosocial behavior [17], namely, self-esteem which plays a role of $39.3 \%$ in influencing the value of gratitude.

Overall, when viewed from the empirical mean, the variables in this study have a high value compared to the hypothetical mean. In the gratitude variable, it can be explained that, as part of the acceptance and healing 
gratitude process, it changes emotions from neglect to a positive thing so that they can be accepted and grateful for. This acceptance and change also change the individual's self-esteem attitude so that the self-esteem value in this study is inversely proportional to Hart et al., In Corwin and Keshin [31].

Aspects of gratitude by McCullough et al., [15] when viewed from prosocial behavior in this study it was found that there is a difference, this is supported according to Ma et al., [34] because, gratitude plays a role in underlying individual behavior in dealing with others, and by Peterson and Seligman [17] who describe the importance of gratitude in maintaining long-term relationships.

In the self-esteem variable, prosocial behavior according to Voss [35] has an impact on increasing self-esteem values and it is explained by Zuffianò et al., [36] that individuals who behave in this way increase social ties and create an environment that is more supportive of positive friendships.

Referring to Rosenberg's theory which divides self-esteem into two aspects, namely positive and negative assessments, Owen in Ervin and Stryker [21], explains that self-confidence plays a role in assessing self-efficacy, specifically in this study is a non-academic achievement.

\section{CONCLUSIONS}

From the results of the main data analysis in this study, it was found that there was a significant role of self-esteem as a predictor to the adult gratitude whom victims of psychological neglect in childhood.

This study provides empirical evidence that there is a relationship between the self-esteem of adult individuals who are victims of psychological neglect in childhood with the value of gratitude. for further research on this topic, we can suggest several things, including:

(a) Explore other things that affect gratitude such as religiosity, pro-social behaviour, and welfare in individual victims of psychological neglect in Indonesia.

(b) Conducting a qualitative follow-up study to determine other factors that influence the high value of gratitude and self-esteem in childhood victims of psychological neglect in Indonesia.

The suggestion from us as the researcher to the practitioners in the social field is to try educate and conduct training on gratitude, as part of self-healing from the negative experiences of psychological neglect in childhood. To future parents, what suggest to prepare as well as possible to meet the child's needs, specifically psychologically by providing support and appreciation without expecting expectations beyond the child's ability, and helping children to be grateful for various things in life to have a better quality of life, by providing many activities.

\section{REFERENCES}

[1] World Health Organization. (2020, June 8). Child maltreatment. https://www.who.int/news-room/fact-sheets/ detail/child-maltreatment

[2] UNICEF. (2012). Child Maltreatment: Prevalence, Incidence and Consequences in the East Asia and Pacific Region: A Systematic Review of Research. UNICEF East Asia and Pacific Regional Office. https://www.unicef. org/eapro/Child_Maltreatment.pdf

[3] Fanetti, M., O’Donohue, W., Happel, R. F., \& Daly, K. (2014). Child abuse and neglect. In Forensic Child Psychology: Working in The Courts and Clinic (pp. 103-124). John Wiley \& Sons, Inc. https://doi.org/ $10.1002 / 9781119171676$

[4] Brandt, A. P. D. M. F. T. (2020, January 3). 9 signs of childhood emotional neglect, and 3 ways to heal. https://www.psychologytoday.com/intl/blog/mindfulan ger/202001/9-signs-childhood-emotional-neglect-and3-ways-heal

[5] Fingerman, K. L., Cheng, Y. P., Wesselmann, E. D., Zarit, S., Furstenberg, F., \& Birditt, K. S. (2012). Helicopter Parents and Landing Pad Kids: Intense Parental Support of Grown Children. Journal of Marriage and Family, 74(4), 880-896. https://doi.org/ 10.1111/j. 1741-3737.2012.00987.x

[6] Khan, R. M., Bushra, M., \& Chohan, I. (2010). Impact of parental support on the academic performance and self concept of the student. Journal of Research and Reflections, 4(1), 14-26. http://www. ue.edu.pk/jrre

[7] Loprinzi, P. D., \& Trost, S. G. (2010). Parental influences on physical activity behavior in preschool children. Preventive Medicine, 50(3), 129-133. https:// doi.org/10.1016/j.ypmed.2009.11.010

[8] Trivette, C. M., Dunst, C. J., \& Hamby, D. W. (2010). Influences of family-systems intervention practices on parent-child interactions and child development. Topics in Early Childhood Special Education, 30(1), 3-19. https://doi.org/10.1177/ 0271121410364250

[9] Wehmeyer, M. L., \& Shogren, K. A. (2017). The development of self-determination during adolescence. In Development of Self-Determination Through the LifeCourse. https://doi.org/10.1007/978-94-024-1042$6 \_7$ 
[10] Soetikno, N., Siregar, J.R., Koesma, R.E., \& Joefiani, P. (2018). Personal Values in Adolescent: Types and Measurement. Advanced Science Letters, 24, 540-542.

[11] Greger, H. K., Myhre, A. K., Klöckner, C. A., \& Jozefiak, T. (2017). Childhood maltreatment, psychopathology and well-being: The mediator role of global self-esteem, attachment difficulties and substance use. Child Abuse and Neglect, 70(September 2016), 122-133. https://doi.org/10.1016/j.chiabu.2017. 06.012

[12] Fasciano, L. C., Dale, L. P., Shaikh, S. K., Little Hodge, A. L., Gracia, B., Majdick, J. M., Holder, A. Y., \& Ford, J. D. (2020). Relationship of childhood maltreatment, exercise, and emotion regulation to selfesteem, PTSD, and depression symptoms among college students. Journal of American College Health, 0(0), 1-7. https://doi.org/10.1080/07448481.2019. 1705837

[13] Wu, Q., Chi, P., Lin, X., \& Du, H. (2018). Child maltreatment and adult depressive symptoms: Roles of self-compassion and gratitude. Child Abuse and Neglect, 80(August 2017), 62-69. https://doi.org/10. 1016/j.chiabu.2018.03.013

[14] Crandall, A. A., Miller, J. R., Cheung, A., Novilla, L. K., Glade, R., Novilla, M. L. B., Magnusson, B. M., Leavitt, B. L., Barnes, M. D., \& Hanson, C. L. (2019). ACEs and counter-ACEs: How positive and negative childhood experiences influence adult health. Child Abuse and Neglect, 96(May), 104089. https://doi.org/ 10.1016/j.chiabu.2019.104089

[15] McCullough, M. E., Emmons, R. A., \& Tsang, J. A. (2002). The grateful disposition: A conceptual and empirical topography. Journal of Personality and Social Psychology, 82(1), 112-127. https://doi.org/10.1037/ 0022-3514.82.1.112

[16] Watkins, P. C. (2014). Gratitude and the Good Life. Springer US. https://doi.org/10.1057/ 9781137414816.0012

[17] Peterson, C., \& Seligman, M. E. P. (2004). Character strengths and virtues: a handbook and classification. In Choice Reviews Online (Vol. 42, Issue 01). https://doi.org/10.5860/choice.42-0624

[18] Papalia, D. E., Olds, S. W., \& Feldman, R. D. (2009). Human development (11th ed.). McGraw-Hill.

[19] Feist, J., Feist, G. J., \& Feist, J. (2018). Theories of theories of personality (9th ed.). McGraw-Hill.
[20] Rosenberg, M., Schooler, C., Schoenbach, C., \& Rosenberg, F. (1995). Global self-esteem and specific self-esteem: Different concepts, different outcomes. American Sociological Review, 60(1), 141. https://doi. org/10.2307/2096350

[21] Ervin, L. H., \& Stryker, S. (2009). Theorizing the relationship between self-esteem and identity. In T. J. Owens, S. Stryker, \& N. Goodman (Eds.), Extending Selfesteem Theory and Research (pp. 29-55). Cambridge University Press. https://doi.org/10.1017/ cbo9780511527739.003

[22] Eric Reyes, M. S., Nicole Amistoso, M. G., Alodia Babaran, C. C., Bernadette Bulaong, G. M., Daniel Reyes, V. M., \& Tubig, N. N. (2017). Death anxiety and self-esteem of filipino youths and older adults. North American Journal of Psychology, 19(2), 435450.

[23] Cooper, K., Smith, L. G. E., \& Russell, A. (2017). Social identity, self-esteem, and mental health in autism. European Journal of Social Psychology, 47(7), 844- 854. https://doi.org/10.1002/ejsp.2297

[24] Vaughan-Johnston, T. I., Lambe, L., Craig, W., \& Jacobson, J. A. (2020). Selfesteem importance beliefs: A new perspective on adolescent self-esteem. Self and Identity, 00(00), 1-22. https://doi.org/10.1080/ 15298868.2019.1711157

[25] Masselink, M., Van Roekel, E., \& Oldehinkel, A. J. (2018). Self-esteem in early adolescence as predictor of depressive symptoms in late adolescence and early adulthood: The mediating role of motivational and social factors. Journal of Youth and Adolescence, 47(5), 932-946. https://doi.org/10.1007/s10964- 017$0727-\mathrm{z}$

[26] Bernstein, D. P., Stein, J. A., Newcomb, M. D., Walker, E., Pogge, D., Ahluvalia, T., Stokes, J., Handelsman, L., Medrano, M., Desmond, D., \& Zule, W. (2003). Development and validation of a brief screening version of the Childhood Trauma Questionnaire. Child Abuse and Neglect, 27(2), 169190. https://doi.org/10. 1016/S0145-2134(02)00541-0

[27] Teicher, M. H., \& Samson, J. A. (2013). Childhood maltreatment and psychopathology: A case for ecophenotypic variants as clinically and neurobiologically distinct subtypes. American Journal of Psychiatry, 170(10), 1114-1133. https://doi.org/10. 1176/ appi.ajp.2013.12070957

[28] Baumrind, D. (2012). Authoritative parenting revisited: History and current status. Authoritative Parenting: Synthesizing Nurturance and Discipline for 
Optimal Child Development., 11-34. https://doi.org/10. 1037/13948-002

[29] Fanetti, M., O’Donohue, W., Happel, R. F., \& Daly, K. (2014). Child abuse and neglect. In Forensic Child Psychology: Working in The Courts and Clinic (pp. 103-124). John Wiley \& Sons, Inc. https://doi.org/ $10.1002 / 9781119171676$

[30] Tower, C. C. (2014). Understanding Child Abuse and Neglect.

[31] Corwin, D. L., \& Keeshin, B. R. (2011). Estimating present and future damages following child maltreatment. Child Adolescent Psychiatric Clinic, 20(3), 505- 518. https://doi.org/10.1016/j.chc.2011.03. 005

[32] Rosenberg, M. (1965). Society and the adolescent self-image. Princeton University Press.

[33]Asif, A., Khalid, Z., Ashraf, M. Z., Khan, H., \& Pervaiz, S. (2018). Gratitude \& self esteem among college students. Journal of Psychology \& Clinical Psychiatry, 9(4). https://doi.org/10.15406/jpcpy.2018. 09.00546

[34] Ma, L. K., Tunney, R. J., Ferguson, E., Ma, L. K., Tunney, R. J., \& Ferguson, E. (2017). Supplemental material for does gratitude enhance prosociality?: A meta-analytic review. Psychological Bulletin. https:// doi.org/10.1037/bul0000103.supp

[35] Voss, K., Markiewicz, D., \& Doyle, A. B. (1999). Friendship, marriage and selfesteem. Journal of Social and Personal Relationships, 16(1), 103-122. https://doi. org/10.1177/0265407599161006

[36] Zuffianò, A., Eisenberg, N., Alessandri, G., Luengo Kanacri, B. P., Pastorelli, C., Milioni, M., \& Caprara, G. V. (2016). The Relation of Pro-Sociality to SelfEsteem: The Mediational Role of Quality of Friendships. Journal of Personality, 84(1), 59-70. https: //doi.org/10.1111/jopy.1213

[37] Alkozei, A., Smith, R., \& Killgore, W. D. S. (2019). Implicit self-esteem is associated with higher levels of trait gratitude in women but not men. Journal of Positive Psychology, 14(5), 587-592. https://doi.org/10.1080/ 17439760.2018.1497691

[38] Jiang, H., Chen, G., \& Wang, T. (2017). Relationship between belief in a just world and Internet altruistic behavior in a sample of Chinese undergraduates: Multiple mediating roles of gratitude and self-esteem. Personality and Individual Differences, 104, 493-498. https://doi. org/10. 1016/j.paid.2016.09.005
[39] Wu, Q., Chi, P., Lin, X., \& Du, H. (2018). Child maltreatment and adult depressive symptoms: Roles of self-compassion and gratitude. Child Abuse and Neglect, 80(August 2017), 62-69. https://doi.org/10.1016/j.chiabu. 2018.03.013

[40] Bartlett, M. Y., Valdesolo, P., \& Arpin, S. N. (2020). The paradox of power: The relationship between selfesteem and gratitude. Journal of Social Psychology, 160(1), 27-38. https://doi.org/10.1080/00224545.2019. 1601609

[41] Chen, L. H., \& Wu, C. H. (2014). Gratitude enhances change in athletes' self-esteem: The moderating role of trust in Coach. Journal of Applied Sport Psychology, 26(3), 349-362. https://doi.org/10.1080/10413200.2014. 889255 